\title{
Head Teachers Management of Resources for Implementation of Integration Programmes for the Intellectually Challenged Learners in Primary Schools in Maara District Kenya
}

\author{
Caroline Kaari Mputhia \\ School of Education, Mount Kenya University \\ Email: carolinekaarin@gmail.com
}

\author{
Doi:10.5901/mjss.2014.v5n5p
}

\begin{abstract}
The head teachers are charged with the responsibilities of management of schools in Kenya. School head teachers, as decision-makers, are continually confronted with problems of managing school resources and funds. With so much at stake resting upon the head teachers' decisions, it is necessary that they should be well informed about the many facets of their demanding job. School head teachers are confronted with literally hundreds of small spontaneously occurring leadership problems to be solved in their day-to-day management of their schools. Despite the government's efforts to ensure that there is effective management of special schools and integrated programmes for the intellectually challenged, still remains a concern to educationist and stakeholders about the issue. No known study has been conducted in the area on the head teacher's management of resources in integrated programmes for intellectually challenged. Thus the study aimed to establish how the head teachers manage the resources for the implementation of integration programmes for the intellectually challenged learners in Maara district
\end{abstract}

\section{Background to the Study}

Education is a powerful instrument of social change and often initiates upward movement in the social structure thereby, helping to bridge the gap between the different sections of society. There has been a strong national movement to include all students in the regular neighborhood schools and classrooms (Stainback \& Stainback, 1990). Inclusion is defined as educating all students in the mainstream for all of the day (Lusthaus \& Forest, 1989). All students, regardless of disability, are educated in the integrated, general education class. Regular teachers are asked to provide experiences that are appropriate for all of their students. The special education teacher provides support in the regular classroom (Stainback \& Stainback, 1992). The resource room is at least partially replaced with the special education teacher consulting from room to room.

Inclusion originated in New Zealand, England, and Canada where it is currently being implemented (Gage, 1994). There are also a number of schools in Italy, Australia, and the United States that are successfully implementing inclusion (Stainback \& Stainback, 1988). In mainstreaming programmes the children were seen as the primary responsibility of the resource teacher (Stainback \& Stainback, 1988). After the World Conference on Special Needs Education in Salamanca in 1990s, inclusion became the magic word in the educational field. The Salamanca Statement adopted by representatives of 92 Governments and 25 International Organizations has, in fact, set the policy agenda for inclusive education on a global basis. Inclusive education refers to all learners, young people - with or without disabilities being able to learn together in ordinary pre-school provisions, schools and community educational settings with appropriate network of support services. The Salamanca Statement of 1994 calls for ordinary schools to include all children, regardless of their physical, intellectual, social, emotional or linguistic or other conditions. Agreed by representatives of 92 governments and 25 international organizations at the World Conference on Special Needs Education in Salamanca, Spain, the Statement reaffirms a commitment to Education for All and recognizes the necessity and urgency of providing education for all children, young people and adults "within the regular education system" and adds UNESCO (1994).

According to UNESCO (2004), everyone who wishes to be schooled and educated should be entitled to enjoy the following: equal access to opportunities for basic learning with peers, equality in terms of good quality experiences that will allow them to complete basic education and equality in the assurance that their education will provide them with the skills to become useful and contributing members of the community. The Statement and Framework for Action from the UNESCO (2004) World Conference on Special Needs Education echo the themes that ordinary schools should seek to accommodate all children, regardless of their physical, intellectual, emotional, social, linguistic or other requirements. It further affirms that national educational policies should stipulate that children attend the same neighborhood schools they 
would attend if they did not have a disability.

Most educators believed that children with physical, sensory, or intellectual disabilities were so different that they could not participate in the activities of a common school (Advani, 2002). Special education programmes in earlier times were, therefore, heavily dependent on voluntary initiative. Christian missionaries, in the 1880s, started schools for the disabled as charitable undertakings (Mehta, 1982).

The Government of Kenya is committed to the provision of equal access to quality and relevant education and training opportunities to all Kenyans. Towards this goal, the government has ratified and domesticated various global policy frameworks on education. The government signed Article 26 of the Universal Declaration of Human Rights (1948), consequently recognizing and committing to the right of every child to access education. The Article recognizes the intrinsic human value of education, underpinned by strong moral and legal foundations Educational opportunities for children (learners) with special needs and disabilities is a major challenge to the education sector. The national education system has been characterized by lack of systems and facilities that respond to the challenges faced by learners with special needs. The United Nations Standard Rules on the Equalization of Opportunities, rule 6 not only affirms the equal rights of children, youth and adults with handicaps to education, but also states that education should be provided "in integrated school settings" and "in the general school setting". There is need to link inclusive education with wider community-based programmes for people with special needs and disabilities.

Special needs education started in Kenya after the end of the Second World War (Kenya Government,2008) Education to these children was only offered in special schools until the 1970s when units and integrated programmes were initiated. However, Educational opportunities for children (learners) with special needs and disabilities are a major challenge to the education sector. The national education system has been characterized by lack of systems and facilities that respond to the challenges faced by learners with special needs.

According to (Kenya Government,2008) majority of learners with special needs and disabilities in Kenya do not access educational services. For instance, in 1999 there were only 22,000 learners with special needs and disabilities enrolled in special schools, units and integrated programmes. This number rose to 26,885 in 2003 (Kenya Government, 1999). This compares poorly with proportion in general education. Currently, there are over 1100 integration programmes and 100 public special schools in the country. In view of the above, this situation calls for a re-appraisal of available approaches to expand Special Needs Education services so as to achieve an enrolment rate at par with that of other children. To attain this, Kenya needs to ensure the realization of inclusive education and simultaneously develop and implement guidelines that mainstream special needs education at all levels of the education system.

The government of Kenya has introduced free primary education where it has set funds for buying teaching/learning materials in all public primary schools in Kenya. It has gone further in providing more funds to learners with special needs so as to purchase teaching and learning materials and assistive devices. In the year 2007, there were disbursements of 4,000 shillings per child in special schools and units (MOE 2007). Currently the government allocates 2,000 shillings per child in special schools and units which is also meant for teaching and learning materials and assistive devices (MOE 2011). As you can observe, the government is giving more funds to learners with special needs for teaching and learning resources as comparing with the other learners in normal primary schools. No known study has been conducted in the area on the head teacher's management of resources in integrated programmes for intellectually challenged. Thus the study aims to establish how the head teachers manage the resources for the implementation of integration programmes for the intellectually challenged learners in Maara district

\section{Assumptions of the Study}

The study was carried out on the basis of the following assumptions

i. That the school head teachers have the required information for the study and will be co-operative during the study.

ii. That all respondents targeted by this study will be available , co-operative and truthful during the study

\section{Theoretical Framework}

\subsection{Administrative Approach Theory}

This study was guided by the administrative approach theory advanced by Henry Fayor (Fayol 1916). In this theory Fayol identified five administrative task areas. These task areas are; financial management, human resource, curriculum, physical and school community. The qualities of these components are critical to accessing education at all levels. Henry 
Fayol model shows that good school manager's deals with tasks that entail financial, human, curriculum, physical and community management. The theory is relevant to this study because it is conceptualized that the head teacher needs to mobilize the above tasks in order to provide access to educational services to the intellectually challenged learners. This theory has been borrowed because school management includes resource management that improves access to education.

\subsection{Cognitive Management Theory}

This theory is revealed in the works of Psacharopoulos and Woodhall (1985). This theory models behavior of a firm as an open system that to a great extent its productivity is influenced by external and internal factors of management. The theory explains psychosocial functioning of a firm such as school in terms of triadic reciprocal causation. In this theory behavior, cognitive and other personal factors and environmental events operate as interacting determinants that influence each other bidirectional to bring about a myriad of management challenges to such firms. In theory if all factors were held constant the output of any firm would be a 100\%. However, due the external factors and other contextual factors, the output falls below the expected $100 \%$ depending on the intensity of all factors. In principle the production process in an integrated programme can be modeled similarly to that of a firm. In this case, the inputs are in form of; enrolled pupils, teachers, finances and staff among others which are drawn from external environment. Just like the firm, the integrated programme output is affected by various factors to cause wastage. Among the requisite factors to wastage are the challenges facing integrated programme management due to lack of finances, low enrolments, understaffing, and inadequate training.

\section{Literature Review}

\subsection{Integration Programmes for Intellectually Challenged in Kenya}

Integration has been defined differently by different writers. Randiki (2002), defines integration as the provision of educational services to children with special need within the regular school systems. Hegarty (1981), defines integration as participation of learners with special needs education in regular education without demanding changes in curricular provision. Berc (1984), refers to integration as the inclusion of the handicapped person in as many cultural activities as possible. Integration means placing handicapped individuals in regular schools to increase their participation in educational and social life. Intellectually challenged learners need special assistance so as to cope in the regular school. This assistance can be provided in a resource room to work with the specialist teacher or use of appropriate teaching and learning resources in the class.

Kauffman and Paynen (1975), states that integration allows children to have an opportunity to explore and learning and also gives parents of the non handicapped youngsters the chance to interact closely with parents of children who have moderate to severe problems. This interaction help in discussing issues of education for the learners and the parents learn more from one another and hence help their children even at home. Parents also get to learn that there is need to use real objects at home which help the children to acquire more skills. Berc (1984) states forms of integrations

- Locational/ physical integration

- Social

- Functional

- Societal

Integration can be successful when educators, managers, parents work together and help one another. Rena (1987) says that integration occurs when success is probable when special learners have the necessary skills; they are included in the regular schools.

Macmillan (1982) suggested that much work in integration remained to be done in developing the skills and techniques required for successful implementation of the principle. Hutt (1979) advocated the right of all children to acceptance within the school programs, regardless of how they deviate from the norms in appearance, performance or behavior. When integrating intellectually challenged learners, it is important to consider that they requires real objects or learning aids to enable them understand the concept being taught. The use of teaching/ learning resources enables them to remember what has been taught this stimulate and facilitate learning. In conclusion, integration can be successful when educators, managers, parents work together and help one another. Rena (1987) says that integration success is probable when special needs learners have the necessary resources to be included in the regular schools. 


\subsection{School Headship in Integrated Programmes}

Appointment to school leadership in Kenya has undergone several phases of change. Initially head teachers were appointed on recommendation by the stakeholders. Later on their appointment was based on seniority. Currently the appointment is based on merit. After graduation from colleges with Diplomas or Degrees in Education, teachers are posted to various public primary schools in the country by the TSC. Their promotion to leadership depends on their seniority and performance. According to the National Policy on Appointment, Deployment and Training of School Administrators and Managers, up to 1987 TSC used to appoint principals who were identified as suitable by the head teachers, politician, school sponsor or TSC field agents. Additionally, the teacher had to be excellent in teaching with a minimum of three years experience as well as good moral behavior and integrity. However, such arrangement could be abused by head teachers, politicians or sponsors picking on a person of their choice who may be lacking the qualities cited. Studies have also shown that being a good classroom teacher does not automatically mean one can make an effective school leader (Bush \& Oduro, 2006). Nevertheless, in 1988 after the implementation of the schemes of service for graduate and graduate approved teachers, principals' positions became deployable after promotion to job groups $L$ to $\mathrm{R}$ where a teacher becomes a head of department, deputy principal, principal, senior principal and chief principal (ibid).

Currently, headship positions are advertised and teachers subjected to rigorous interviews before they are appointed by the TSC (Rarieya, 2007). The National Policy on Appointment, Deployment and Training of School Administrators and Managers says that head teachers have to be trained before and after appointment to school leadership.

\subsection{Resources for the Intellectually Challenged Learners in Integration Programmes}

According to Ngugi (2002), intellectually challenged learners have conditions that hinder normal learning and development. This means that they require a lot of resources to enable them understand a concept being taught. Njeri (1990), states that resources enhance interest, comprehension, retention and concreteness to any learning. Learning is more effective when appropriate resources have been used to fit in the curriculum. School resources can be categorized as;

- Financial Resources

- Physical and Material Resources

- Human Resources

\subsection{School Management of Financial Resources in Integrated Programmes}

School head teachers, as decision-makers, are continually confronted with problems of managing school resources. With so much at stake resting upon the head teachers decisions, it is necessary that they be well informed about the many facets of their demanding job. According to Leithwood and Stainback (1995), school head teachers are confronted with literally hundreds of small spontaneously occurring leadership opportunities (problems to be solved) in their day-to-day management of their schools. Chapman and Aspin (1999) contend that the government, as the provider of formal education and as the custodian of the public purse, should set up appropriate and workable accountability mechanisms. School head teachers are therefore required to establish an adequate accounting system so as to achieve the greatest economy possible in the management of the school's resources.

Management of school resources comprises a cycle of financial planning, organization, leading/guiding and control (Rees and Porter 1996 1992). Studies by Sagor and Barnett (1994) agree that policies and guidelines are essential, because they help to make or determine appropriate actions. These policies and guidelines become the working norms of the school rather than formal board policies or statements of operating procedures. Typically, they dictate what will not be tolerated in reaching the mission. Murphy and Louis (1999) refer to the popular trend of delegating the management of school resources to school head teachers as an increase in the allocation of decision-making, school-based management and participative decision-making.

According to Earley (1999) school head teachers should be empowered to understand and supervise school resources. Earley maintains that school head teachers should work with their in the financial matters dealing with budgeting, purchasing and in managing school resources. According to Earley (1999), school head teachers need not necessarily be financial experts or accountants, but it is believed that they should be knowledgeable enough to keep on top of the school's budget and accounting process and knowledgeable enough to speak and understand the relevant language. 


\subsection{Physical and Material Resources for the Intellectually Challenged Learners}

Intellectually challenged learners requires to use more than one senses in learning to make learning more real and to enable them remember what has been taught. Saunders (2004) noted that visual arouses interests, give accurate impression, help in memory, stimulates the imagination and provide a shared experience. Teachers need to realize that when they engage visual senses in learning, it is more real and this can be retained for a longer period.

According to Douglas (1964) learning can be acquired through the five senses analyzed as follows

i. We retain $83 \%$ of what is learnt through sight

ii. We retain $1 \%$ of what is learnt through smell

iii. We retain $1 \%$ of what is learnt through taste

iv. We retain $1 \%$ of what is learnt through touch

v. We retain $1 \%$ of what is learnt through hearing

This should help the educators know that visual learning is more important in learning than the auditory that is commonly used by the educators. If more than one sense is engaged in learning of the use of the use of multi sensory approach helps in teaching intellectually challenged learners. Learning resources helps them to understand through the use of more than one sense. Use of resources help them to understand the concept being taught and enables them see learning more real and it motivates them to participate in the learning. According to Clarissa Willis (2009) learning resources should be purchased to be used in the classroom in the learning situations. This enables the teachers have adequate resources that are used in teaching and hence help the learners have a strong visual memory.

The school climate is determined by the available resources in the school that are available for use by the pupils. The quality of these resources also affects the quality and amount of learning that the students retain. According to (Uwheraka 2005) facilities below the approved standards could also lead to reduction in the quality of learning in school resulting to poor performance.

Resources for integrated programmes can be categorized into physical and material resources. Onyango (2001) indicates that material resources are items so designed to assist in teaching and learning activities in schools. Some of the material resources used for learning in integrated programmes include: text books, charts, communication boards, counting trays, abacus, jigsaw puzzle, shape boards, finger puppets, chalk board, furniture among others. Physical resources in a school include all the buildings and other support facilities in the school (Bhakada 2004). These include; administration offices, classrooms, workshops, resource rooms, toilets, dormitories, dining rooms among others. Other resources include human resource, which includes teaching and support staff in the schools, and financial resources among many others.

\subsection{Human Resource Management in Integration Programmes}

Human resource is defined as any human support in learning. These are the persons who participate and contribute to meet the learning needs of learners. In teaching learners with special needs in an integrated setting, consideration should be made of human resources who should offer appropriate support to learners who are intellectually challenged. These include: special trained teachers, school nurse, cooks, watchman, educational psychologists, social workers, physiotherapists among others. The head teacher is charged with the responsibility of management of school resources which includes the human resources.

The success of every educational system depends on the quality and quantity of its factors or production - human and material resources. Of all the factors, the human resource seems to be the most important because without human efforts, all other factors are inept. This is why it is necessary to train and re-train the staff of any organization for better production.

According to Peretomode (2001), training is a planned organizational effort concerned with helping an employee (teachers and support staff) acquires specific skills, knowledge, concepts, aptitudes, and behaviors to enable him/her perform more efficiently on his present job, that is, to improve on the performance. The success of our education depends on staff training. We cannot replace trained staff with any other type of instructional tools or material (Hanif and Saba 2002). This is because the quality of staff in any educational system determines to a great extent the quality of the system itself, and professional staff in particular is crucial to the formulation and successful implementation of educational policies and programmes in any country. Every training is designed to enable Organization achieve pre-determined goals and objectives. Therefore to determine training needs involves some elements of diagnoses in order to set acceptable objectives.

Some means of assessing training needs are: 
1. Performance Appraisal: This approach of job appraisal can reveal a worker's inadequacies and class management components for appraisal necessitate a need for training to help the employee overcome the weakness. This training is designed as a corrective or remedial measure.

2. Job Requirement: This examines job descriptions and specifications in order to highlight the job content and requirements for performance. Training can then be developed from information gathered in order to provide the needed skills and abilities or retraining in needed skills for current jobs.

3. Organizational Analysis: The analysis of the strategies and objectives of an organization will help identifying training needs before those needs become critical.

4. Survey: A survey of both managerial and no managerial employees can provide some insight into expressed employee problems and possible actions or remedies. Sometimes such surveys can reveal individualized description of employee dissatisfaction in the organization in the organization. The purpose of using survey is to gather useful information on workers problems.

Manpower development can be defined as activities concerned with increasing the workers capabilities for continuing growth in the organization. The main purpose of manpower development is to enlarge an employee's capability to successfully handle greater responsibilities. Although development includes some skill development and it is more specifically oriented toward a person's capacity to handle future responsibilities. Training has an implication for the staff in service, the need to develop on the job and keep abreast with the continual changes in the job which may be conditioned by changes in the environment in terms of scientific, technological and socio-cultural and economic advancement.

Peretomode (2001) highlighted the determinants of training as acquiring more conceptual knowledge, skills and competencies both in teaching areas and non-teaching areas, obtain high academic or professional qualifications in school / organization, to meet up with the new changes in the educational system, the new methods, techniques and technological developments, to keep the staff in the system, procure job security. The government comes with different policies at different times. Those who improved themselves on the job have greater chances on the job, and also the presence of aging staff and explosion of knowledge has been noted that with age, human beings suffer from diminished validity, creativity and flexibility, staff can be assisted to remain or once again become vibrant, vital, productive and pertinent through staff renewal activity, the declining rate of mobility and high tenure density coupled with less hiring new blood, the increasing heterogeneity of staff in the system.

Okoye (1998) in her study endorsed the concept of in-service training for administrative staff of all levels. She stressed that there is need to upgrade quality of leadership, school system and institutions offering education in order to achieve effective programmes of selecting and preparation. However, the training approach of human resources is different and the certificates obtained are equally different. The scientific management principle of school administration of Frederick Taylor believes that performance should be part of each job so that each workman knows his job well (Egwunyenga 2000). Thus, in the training of trained staff, their courses comprise of their main area and education course in which they are introduced to teaching techniques, methods, presentation of lessons, art of classroom management and other factors affecting teaching and learning (Kpangban 1992).

\subsection{Head Teachers as the School Managers}

Studies by (Jackson, 2002) indicate that preparation and development of school head teachers can lead to effectiveness and improvement of the school. As a result, many countries especially in the developed world have come up with institutions and programmes for preparation and development of school head teachers. Conversely, not so much in terms of head teachers' school resources management in the developing world has been brought to the fore though this should not be mistaken for complete lack of head teachers s preparation and development in the developed world. Most studies carried out on principals in Africa (Harbey \& Dadey, 1993) focus mainly on problems facing principals in various contexts.

In Kenya, head teachers are given a lot of responsibilities as school leaders (Teachers' Service Commission (TSC). TSC, a body charged with employment of teachers in Kenya, outline some of the responsibilities of a head teachers as being the accounting officer of the school, interpreting and implementing policy decisions pertaining to training, overall organization, coordination and supervision of activities in the institution as well as maintaining high training and learning standards. These responsibilities can be carried out more effectively with preparation and development for school leadership if mechanisms for the same are in place.

Kenyan education has very high expectations of public school head teachers because they believe that the success of a school is measured in terms of good performance in national examinations and the person responsible for this is the head teachers. Johansson and Pashiardis (2007) state that, "school leadership has become more complex as 
curricular demands have grown, parental, government expectations and demand for greater school effectiveness have been raised". West and Jackson (2002) citing Elmore (2001) agree that "increasing public expectations of schools and their leaders and the accountability demands, also makes it inevitable that head teachers and aspiring head teachers should feel that they have an entitlement to appropriate training and support" Meeting such expectations cannot be achieved unless head teachers s are prepared and developed for school leadership..

Most research and literature on leadership preparation and development is mostly based on the developed world. Harber and Davey (1993) argue that, theories of educational training transferred from America and adopted in African research and training institutions may not work because of the national and cultural differences between these two contexts which are very unique in themselves. Bush and Jackson (2002) elaborate that; this is due to different political, social, and professional contexts and concludes that as a result "what works well in one country may not succeed elsewhere". Head teachers in an integrated programme are faced with challenges from the parents of intellectually challenged learners who are over expectant from their children. This is a problem as he has to work hand in hand with the teachers to help the learners achieve and the parent may feel that their children should achieve more.

\subsection{Challenges Facing Head Teachers in Management of Resources}

A number of studies have highlighted certain problems facing head teachers in many countries. In Ghanaian context these problems include complexity of administrative/managerial roles (Lahui-Ako, 2001); difficulty in collecting and managing school fees (Harber \& Davies, 2002; Oduro \& MacBeath, 2003). Head teachers in Ghana combine teaching with administrative roles, making it difficult for them to make adequate time for management and supervision. Lahui-Ako (2001) also argues that most head teachers in Papua New Guinea are burdened with many responsibilities. However, unlike the situation in Ghana, they are preoccupied with broad administrative responsibilities resulting in the allocation of inadequate time to their instructional leadership roles. According to Lahui-Ako, head teachers are mostly engaged in roles, mainly; Planning infrastructure development, organizing necessary human, financial, and physical resources; directing and controlling staff performances through evaluation and providing feedbacks aimed to achieve desired results with the school rather than using their natural and learned ability, skill, and personal characteristics to influence people to take desired action (Lahui-Ako, 2001).

It is common to find school head teachers who feel that management of school resources is not problematic and who take it for granted as a simple day-to-day operation which could be tackled. Hence many school head teachers would not actively seek avenues for upgrading their resource management competence through appropriate training programmes. However, Preparation and training efforts should take good account of organizational context and constraints within which school head teachers would be operating or working. In addition, a thorough knowledge and appreciation of social, economic, cultural and political factors that impinge on these schools are necessary before meaningful and adaptable training or preparation can be given (Campher. 2002).

The growing demands on effective management of school resources and funds by school head teachers deserve an appropriate response. The traditional pattern of appointing school head teachers is not suitable to address demands placed on them. A school head teacher therefore needs to be well prepared to manage the school resources effectively, because inadequate knowledge on school management methods would lead to inefficiency (Sallis 1997 and Harris and Muijs 2005).

Inefficiency regarding school resource management could be alleviated through providing resource management knowledge, changing attitudes, and by organizing in-service and pre-service training and development programmes for school head teachers as school managers (Head and Watson 1998:).

Head teachers are also entrusted with the responsibility of collecting and managing approved fees on behalf of the stakeholders such as the PTAs and MOE, without being trained for that task (Haber \& Davies, 2002; Oduro \& MacBeath, 2003). However, their salaries are often withheld or suspended in the event of misappropriation or their inability to meet the financial expectations of the stakeholders. Sometimes, they are accused of embezzlement of public funds, tarnishing their image among their colleagues and the people in the community in which they operate (Oduro \& MacBeath, 2003). Unlike the practice in Ghana whereby head teachers are 'school fees collectors', their counterparts in England, have professional accountants or business managers who are charged with the responsibility of managing school finances. This enables head teachers to concentrate on the performance of their leadership and management roles.

\section{Research Design}

The study employed the descriptive research design. According to Creswell (1994) descriptive research design to 
presents facts about the nature and status of a situation as it exist at the time of the study. In addition, it also concerns with the relationships and practices that exist between beliefs and processes that are ongoing and the effects that are being felt or trends that are developing (Kombo \& Tromp, 2006). Therefore, it was helpful in order to describe the conditions and situations based on the impressions and perceptions of the respondents of the study (Creswell 1994). The design was therefore appropriate for this study since the researcher gathered information without manipulation of variables.

The target population of this study comprised of 10 head teachers, 40 teachers for integrated programmes for intellectually challenged learners and 1 DQASO in Maara district. This therefore brings the target population to 51 subjects. This research mainly used three questionnaires. The questionnaires will be structured to establish the Head teachers manage the resources for the implementation of integration programmes for the intellectually challenged learners in primary schools. Questionnaires were administered to teachers in the programme, interview guide for head teachers, interview schedule for DQASO and observation schedule for the learners in the programme.

\section{Results and Discussion}

\subsection{Response Rate}

The study administered the research instruments to the subjects and the response rate is shown by the data on Table 2 .

Table 2: Response Rate

\begin{tabular}{|l|c|c|}
\hline \multicolumn{1}{|c|}{ Respondents } & \multicolumn{2}{c|}{ Expected } \\
\hline & Frequency & $\%$ \\
\hline Headteachers & 10 & 100 \\
\hline Teachers & 26 & 100 \\
\hline DQASO & 1 & 100 \\
\hline Total & 37 & \\
\hline
\end{tabular}

Data on Table 2 indicates that the research was popular among the headteachers teachers and DQASO in those 26 $(100 \%)$ teachers and 10(100\%) headteachers and 1(100\%) DQASO returned the questionnaires. The data further reveals that all the anticipated subjects participated in the study. Therefore $100 \%$ response rate from teachers, headteachers and DQASO was good and quite representative.

\subsection{Demographic Data of Respondents}

The demographic profile provides information about the population structure, and helps create a mental picture of the subgroups that exist in the overall population. Researchers obtain demographic information from the study subjects to understand sample characteristics and to determine if samples are representative of the populations of interest (Kirton, 2000). Although demographic variables cannot be manipulated, researchers can explain relationships between them and dependent variables. In this study, the researcher investigated the respondent's characteristics by establishing their gender, age, academic qualification and experience (length of service).

\subsection{Gender}

The study sought to establish how the sample population was distributed by gender, and enable tabulation of responses in this light. Table 3 data reveals how the study subjects were distributed by gender.

Table 3: Gender Distribution of Respondents

\begin{tabular}{|l|c|c|c|c|c|}
\hline \multirow{2}{*}{ Category of respondent } & \multicolumn{2}{c|}{ Male } & \multicolumn{2}{c|}{ Female } & \\
\cline { 2 - 6 } & Frequency & $\%$ & Frequency & $\%$ & Total \\
\hline Heat teachers & 7 & 70 & 3 & 30 & 100 \\
\hline Teachers & 8 & 30.8 & 18 & 69.2 & 100 \\
\hline
\end{tabular}


According to the findings in Table 3, majority $7(70 \%)$ headteachers were male and 3(30\%) were female, showing that majority schools were headed by male head teachers. Female teachers formed the majority (69.2\%) while (30.8\%) were females. This shows that there is gender disparity in favour of females in the general composition of integration programmes teachers.

Figure 2: An illustration of the above data in form of pie chart

Headteachers

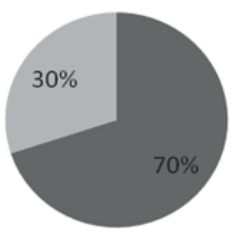

Teachers

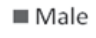

Gemale

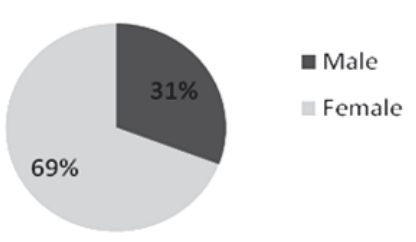

\subsection{Age}

The demographic attribute of age has importance through linkages with individual experience and personal accumulated knowledge. The age distributions of the respondents are shown in Table 4.

Table 4: Age Distribution of Respondents

\begin{tabular}{|c|c|c|c|c|}
\hline \multirow{2}{*}{ Age Interval } & \multicolumn{2}{|c|}{ Head Teachers } & \multicolumn{2}{c|}{ Teachers } \\
\cline { 2 - 5 } & Frequency & $\%$ & Frequency & $\%$ \\
\hline $20-30$ & 0 & 0 & 0 & 0 \\
\hline $31-40$ & 2 & 20 & 6 & 23.1 \\
\hline $41-50$ & 6 & 60 & 19 & 73.1 \\
\hline Over 50 years & 2 & 20 & 1 & 3.8 \\
\hline Total & 10 & 100 & 26 & 100 \\
\hline
\end{tabular}

The study established that the majority $60 \%$ of the headteachers were in the age bracket of $41-50$ years, $20 \%$ were in the age bracket 31-40, and over 50 years. The data also indicates that majority (73\%) teachers were aged between 41 and 50 years, the minority $3.8 \%$ were aged over 50 years. The findings reveal that most of the teachers and headteachers were above 40 years.

Figure 3: An illustration of the above data in form of a bar graph

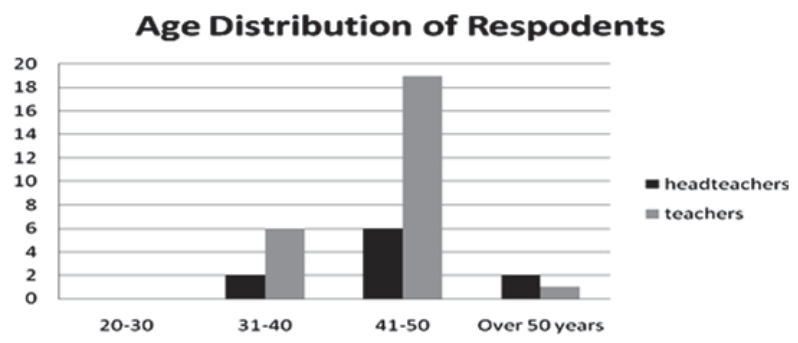

\subsection{Academic Qualification}

The study sought to establish the academic qualification of teachers and the data on Table 5 reveals the findings 
Table 5: Teachers' Academic Qualification

\begin{tabular}{|c|c|c|c|c|}
\hline \multirow{2}{*}{ Qualification } & \multicolumn{2}{|c|}{ Head Teachers } & \multicolumn{2}{c|}{ Teachers } \\
\cline { 2 - 5 } & Frequency & $\%$ & Frequency & $\%$ \\
\hline Masters degree & 0 & 0 & 0 & 0 \\
\hline Bachelor degree & 3 & 30 & 12 & 46.2 \\
\hline Diploma & 4 & 40 & 11 & 42.3 \\
\hline P1 Certificate & 3 & 30 & 3 & 11.5 \\
\hline Total & 10 & 100 & $\mathbf{2 6}$ & 100 \\
\hline
\end{tabular}

The study findings in Table 5 established that $40 \%$ headteachers had a diploma qualification while $30 \%$ had bachelor's degree qualification and P1 certificate. Integration programmes teachers holding bachelor's degree qualification accounted for $46.2 \%$ while the rest $42 \%$ had diploma and $11.5 \%$ had P1 certificate qualifications.

Figure 4: An illustration of the above data in form of a pie chart
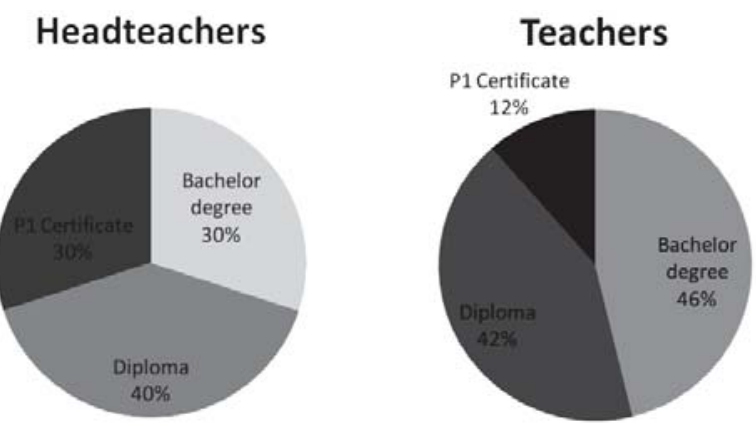

\subsection{Years of Service}

The study sought to establish the academic qualification of teachers and the data on Table 6 reveals the findings

Table 6: Teachers Years of Service

\begin{tabular}{|l|c|c|c|c|}
\hline \multirow{2}{*}{ Years of service } & \multicolumn{2}{|c|}{ Head Teacher } & \multicolumn{2}{c|}{ Teachers } \\
\cline { 2 - 5 } & Frequency & $\%$ & Frequency & $\%$ \\
\hline 1-3 years & 4 & 40 & 2 & 7.7 \\
\hline $4-6$ years & 3 & 30 & 3 & 11.5 \\
\hline 7-9 years & 2 & 20 & 5 & 19.2 \\
\hline 10-12 years & 0 & 0 & 10 & 38.5 \\
\hline Over 12 years & 1 & 10 & 6 & 23.1 \\
\hline \multicolumn{1}{|c|}{ Total } & 10 & 100 & 28 & 100 \\
\hline
\end{tabular}

According to the findings shown on Table 6, majority headteachers (50\%) had been in service as headteachers for 1-3 years while the minority $10 \%$ had served for above 12 years. This implies that most head teachers may be said to have adequate experience in integration programme management.

The findings further shows that majority 38.5\% SNE teachers had been in the teaching service for between 10-12 years while the minority $7.7 \%$ between SNE teachers for 1-3 years. The findings therefore reveal varied years of experience for head teachers and teacher in the teaching service. 
Figure 5: An illustration of the above data in form of a bar graph

\section{Length of service}

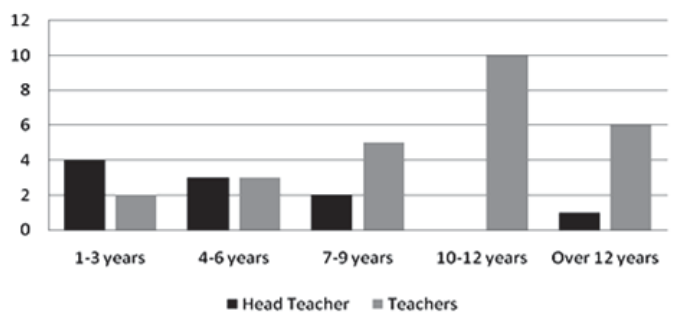

\subsection{Length of Service as an SNE Teacher}

The study sought to establish the length of service of teachers as SNE teacher and the data on Table7 reveals the findings

Table 7: Length of Service as an SNE Teacher

\begin{tabular}{|l|c|c|}
\hline \multicolumn{1}{|c|}{ Years of service } & Frequency & Percentage \\
\hline $1-5$ years & 21 & 80.8 \\
\hline $5-10$ years & 3 & 11.5 \\
\hline $10-15$ years & 1 & 3.8 \\
\hline 15 and above & 1 & 3.8 \\
\hline \multicolumn{1}{|c|}{ Total } & 26 & 100 \\
\hline
\end{tabular}

According to the findings shown on Table majority $80.8 \%$ of teachers had been teaching SNE for between 1-5 years. Minority $3.8 \%$ have been SNE teachers between 10-15 years and 15 years and above. The findings therefore reveal that most of the SNE teachers have little experience years in the teaching SNE in integration programmes.

Figure 6: An illustration of the above data in form of a bar graph

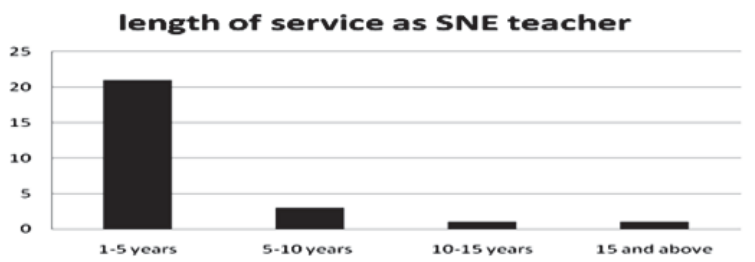

\subsection{Adequateness of Physical and Material Resources}

The school climate is determined by the available resources in the school that are available for use by the pupils. The quality of these resources also affects the quality and amount of learning that the students retain. According to (Uwheraka 2005) facilities below the approved standards could also lead to reduction in the quality of learning in school resulting to poor performance. Resources for integrated programmes can be categorized into physical and material resources. Onyango (2001) indicates that material resources are items so designed to assist in teaching and learning activities in schools.

The study sought to establish the teaching/ learning resources used in teaching intellectually challenged learners in integrated programmes. Respondents were asked to indicate their opinion on issues related to the availability adequateness and condition of some physical and material resources in the school. The adequateness was measured on a four point Likert scale where respondents were required to answer Adequate, Inadequate, In Bad Shape or Not Available. 


\subsection{Adequateness of Physical Resources}

The study sought to establish the Adequateness of Physical Resources and the data on Table 8 reveals the findings

Table 8: Adequateness of Physical Resources

\begin{tabular}{|l|c|c|c|c|c|}
\hline \multicolumn{1}{|c|}{ Facilities } & Adequate & Inadequate & In bad shape & Not available & $\%$ \\
\hline Furniture (desks, tables, chairs) & 66.7 & 30.5 & 2.8 & 0 & 100 \\
\hline Chalk boards & 88.9 & 11.1 & 0 & 0 & 100 \\
\hline Class rooms & 69.4 & 30.6 & 0 & 0 & 100 \\
\hline Resource room & 11.1 & 30.6 & 5.6 & 52.8 & 100 \\
\hline Workshops & 2.8 & 5.6 & 8.3 & 83.3 & 100 \\
\hline Toilets & 52.8 & 41.7 & 0 & 5.6 & 100 \\
\hline Dormitories & 5.6 & 16.7 & 0 & 77.8 & 100 \\
\hline
\end{tabular}

The results on Table 8 indicate definite trends regarding the respondent's impression of adequateness of physical resources. The overall impression from the responses can be summarized as follows: With regard to furniture (desks, tables and chairs), majority $66.7 \%$ respondents agreed that the furniture in their schools is adequate while minority $2.8 \%$ indicated that the furniture in the school was in bad shape. This indicates that the furniture in most of the integration programmes was adequate.

With regards to the adequateness of chalkboards in the school, $88.9 \%$ respondents were in the view that chalk boards were adequate. $11.1 \%$ said that the chalkboards were inadequate. From these findings it can be deduced that the chalkboards in most of the integration programmes were adequate.

Regarding the adequateness of classrooms, most of the respondents $69.4 \%$ agreed that the classrooms were adequate, while $30.6 \%$ were of the view that the classrooms were inadequate. The results show that the classrooms were adequate in the integration programmes.

With regards to the resource rooms, majority $52.8 \%$ indicated that the resource rooms while the minority $5.6 \%$ indicated that the resource rooms were in bad shape. From these findings, it shows that the resource rooms in the integration programmes in Maara district were inadequate and unavailable.

With regards to workshop, $83.3 \%$ indicated that the workshops were not available while the minority $2.8 \%$ of the respondents indicated that the workshops were adequate. These results show that the most of the integration programmes in Maara districts did not have workshops.

Regarding the availability and conditions of toilets and latrines, following responses was elicited: the majority $52.8 \%$ indicated that the toilets were adequate, while $41.7 \%$ indicated that they were inadequate. It can be said from these findings that the toilets and latrines were adequate.

With regards to the dormitories, $77.8 \%$ indicated that the dormitories were not available $5.6 \%$ of the respondents agreed that the dormitories are adequate. From the findings above, it's can be deduced that the dormitories were not available in most of the schools with integrated programmes in Maara District.

Figure 7: An illustration of the above data in form of a bar graph

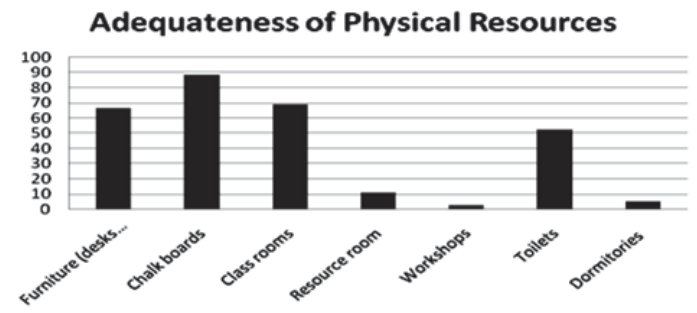

\subsection{Adequateness of Material Resources}

Use of resources help them to understand the concept being taught and enables them see learning more real and it motivates them to participate in the learning. According to Clarissa Willis (2009) learning resources should be purchased 
to be used in the classroom in the learning situations. This enables the teachers have adequate resources that are used in teaching and hence help the learners have a strong visual memory.

The study sought to establish the Adequateness of Material Resources and the data on Table 9 reveals the findings

Table 9: Adequateness of physical and material resources

\begin{tabular}{|l|c|c|c|c|c|}
\hline \multicolumn{1}{|c|}{ Facilities } & Adequate & Inadequate & In bad shape & Not available & $\%$ \\
\hline Communication boards & 2.8 & 22.2 & 0 & 75 & 100 \\
\hline Counting tray & 5.6 & 16.7 & 0 & 77.8 & 100 \\
\hline Abacus & 11.1 & 30.6 & 8.3 & 50 & 100 \\
\hline Jigsaw puzzle & 11.1 & 19.4 & 0 & 69.4 & 100 \\
\hline Shape board & 19.4 & 19.4 & 5.6 & 55.6 & 100 \\
\hline Finger puppet & 8.3 & 13.9 & 0 & 77.8 & 100 \\
\hline Books & 38.9 & 52.8 & 0 & 8.3 & 100 \\
\hline
\end{tabular}

The results on Table 9 indicate definite trends regarding the respondent's impression of adequateness of material resources. The overall impression from the responses can be summarized as follows: With regard to communication board, majority $75 \%$ indicated that the communication boards in the school ware inadequate while $2.8 \%$ respondents agreed that the communication boards in their schools is adequate. This show that the communication boards were inadequate in most of the integration programmes in Maara district.

Regarding the adequateness of counting tray, the respondents elicited the following responses: Majority $77.8 \%$ agreed that the counting trays were not available. The minority $5.6 \%$ agreed that the counting trays were adequate. The results show that majority respondents feel that the counting trays were not available in the integration programmes.

With regards to the availability of Abacus, $50 \%$ of the respondents indicated that abacus were not available while 8.3\% indicated that the abacus were in bad shape. From the above results, it's clear that abacus in the integration programmes in Maara district were not available.With regards to jigsaw puzzle, $69.4 \%$ indicated that the jigsaw puzzle were not available while $11.1 \%$ of the respondents indicated that the jigsaw puzzle were adequate. These results show that the majority of the integration programmes in Maara districts did not have jigsaw puzzle.

Regarding the availability and conditions of shape boards, following responses was elicited: majority $55.6 \%$ indicated that shape boards were not available while minority indicated $5.6 \%$ in bad shape. It can be said from these findings that shapeboards were not available. With regards to finger puppets, majority $77.8 \%$ respondents indicated that they were not available while the minority $8.3 \%$ respondents indicated that they were adequate. These results show that the finger puppets in most of integration programmes in Maara district were not available.

Regarding the availability and conditions of books, following responses was elicited: majority $52.8 \%$ respondents indicated that the furniture was inadequate while $8.3 \%$ indicated that the furniture was not available. It can be said from these findings that majority respondents said that the furniture were inadequate.

Figure 8: An illustration of the above data in form of a bar graph

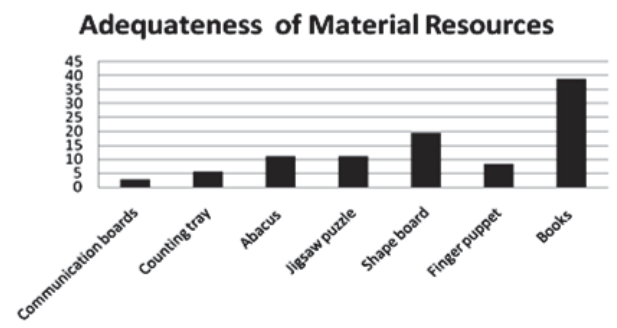

\subsection{Adequateness of Financial and Human Resources}

The study sought to establish the Adequateness of Financial and Human Resources and the data on Table 10 reveals the findings 
Table 10: Adequateness of Financial and Human

\begin{tabular}{|l|c|c|c|c|c|c|}
\hline \multicolumn{1}{|c|}{ Variables of Financial and Human Resources } & SA & A & UN & D & SDA & $\%$ \\
\hline You receive any funds from the government & 0 & 60 & 0 & 40 & 0 & 100 \\
\hline The funds are adequate & 0 & 0 & 0 & 100 & 0 & 100 \\
\hline You receive these funds regularly & 0 & 10 & 0 & 90 & 0 & 100 \\
\hline There is adequate teaching staff & 5.6 & 30.6 & 2.8 & 52.8 & 8.3 & 100 \\
\hline The students and staff are provided with essential stationery in time & 13.9 & 30.5 & 13.9 & 30.5 & 11.1 & 100 \\
\hline Head teacher is involved in recruitment of non-teaching staff & 25 & 19.4 & 11.1 & 33.3 & 11.1 & 100 \\
\hline Head teacher highly motivate teachers and other staff & 16.7 & 25 & 8.3 & 41.7 & 8.3 & 100 \\
\hline
\end{tabular}

Regarding to whether the schools received funds from the government, $60 \%$ of the respondents agreed that they did receive the funds from the government. $40 \%$ disagreed receiving any funds from the government. However regarding the adequateness of the of these government funds, all the respondents said that the funds were inadequate. It can be said that the government supports SNE by funding the integration programmes but the funds are inadequate.

In regard to whether the funds are dispatched regularly, $90 \%$ the respondents said that the funds were not received regularly. $10 \%$ agreed that they received the funds regularly. This means that the government funds the integration programmes on irregular basis. Regarding the adequateness of teaching staff, (5.6\%) strongly agreed while $30.6 \%$ agreed. $2.8 \%$ were undecided while $52 \%$ disagreed $8.3 \%$ strongly disagreed. The result therefore indicates that the teaching staff was inadequate.

Another variable of human resource management that the study explored was whether the students and staff are provided with essential stationery in time. Regarding this aspect, $13.9 \%$ respondent strongly agreed, $30.5 \%$ agreed, while $13.9 \%$ remained neutral. Another $30.5 \%$ disagreed while $11.1 \%$ strongly disagreed. On this aspect of management, the study revealed that students and staff were provided with essential stationery in time.

Regarding head teachers involvement in recruitment of non academic staff, (25\%) strongly agreed while $19.4 \%$ agreed. $11.1 \%$ were undecided, $33.3 \%$ disagreed while 11.1 strongly disagreed. The result therefore indicates that headteachers were not effective in recruitment of support staff.

Regarding the effectiveness of headteachers in motivating staff, $16.7 \%$ respondents strongly agreed, $25 \%$ agreed, $8.3 \%$ undecided, $41.7 \%$ disagreed and $8.3 \%$ strongly disagreed. It can be shown from this data that majority (41.7\%) disagreed and that the head teachers were not effective in motivating staff highly.

Other sources of funds for the integration programmes highlighted during the study include; parent's contributions as supported by (55.5\%), donors funding (22.2\%) and community development fund CDF (22.2\%).

\subsection{Headteachers Management of School Resources}

The study sought to establish the effectiveness of headteachers towards management of school resources for the integration programmes. Respondents were asked to indicate their opinion on issues related to physical facilities. The findings are revealed on Table 11.

Table 11: Headteachers Management of School Resources

\begin{tabular}{|l|c|c|c|c|c|c|}
\hline \multicolumn{1}{|c|}{ Variables of Physical and material resource Management } & SA & A & UN & DA & SDA & $\%$ \\
\hline You constantly inspect facilities for the integration programmes classrooms & 50 & 50 & 0 & 0 & 0 & 100 \\
\hline $\begin{array}{l}\text { You ensure that there are enough learning resources for all students in the } \\
\text { integration programmes }\end{array}$ & 20 & 50 & 10 & 20 & 0 & 100 \\
\hline Your integration programme has well maintained classrooms & 40 & 30 & 0 & 20 & 10 & 100 \\
\hline Your integration programme has well maintained furniture & 10 & 20 & 10 & 60 & 0 & 100 \\
\hline Your integration programme has well equipped resource rooms & 0 & 0 & 0 & 60 & 40 & 100 \\
\hline You conduct routine facility maintenance and upgrading & 10 & 40 & 20 & 30 & 0 & 100 \\
\hline You supervise time management in the school & 40 & 50 & 10 & 0 & 0 & 100 \\
\hline
\end{tabular}

Legend: S A (Strongly agree-scored 5), A (Agree-scored 4), UN (Undecided-scored 3), DA (Disagree-scored 2), and SDA (Strongly Disagree- scored 1)

Data on Table 11 presents findings form broad variables of management of school resources that the study investigated. Regarding headteachers involvement in inspect facilities for the integration programmes classrooms, majority (50\%) 
strongly disagreed while another 50\% agreed. The result therefore indicates that headteachers did inspection to the school facilities.

With regard to ensure that there are enough learning resources for all students in the integration programmes, 20\% respondents strongly agree to the statement that headteachers ensure that there are enough learning resources for all students in the integration programmes. Similarly 50\% respondents agreed, 10\% were undecided while another 20\% indicated that they disagreed. No respondents indicated strong disagreement with this aspect of management. Majority of the respondents felt that the head teachers ensure that there are enough learning resources for all students in the integration programmes.

With regard to whether integration programme has well maintained classrooms, $40 \%$ respondents strongly agreed, $30 \%$ said they agreed, $20 \%$ were disagreed and $10 \%$ indicated they strongly disagreed. From these findings, it is shown that most of the respondents that strongly agreed that integration programme have well maintained classrooms. It can therefore be deduced that the integration programme have well maintained classrooms.

Regarding whether integration programme has well maintained furniture, elicited the following responses: $10 \%$ strongly disagreed, $20 \%$ agreed, $10 \%$ were undecided, and another $60 \%$ disagreed. None strongly disagreed. The results show that majority respondents feel that integration programme do not have well maintained furniture as reflected by $60 \%$ responses that agree.

Regarding whether integration programme have well equipped resource rooms the following responses were elicited: $60 \%$ disagreed while another $40 \%$ strongly disagreed. No respondents' record any agreement or undecided. The result clearly reflects that integration programme do not have well equipped resource rooms.

Regarding the headteachers conducting routine facility maintenance and upgrading, 10\% respondents strongly agreed and majority 40\% agreed. 20\% were undecided while 30\% disagreed. From the findings it can be adduced that headteachers conductited routine facility maintenance and upgrading in integration programmes.

Regarding headteachers supervise time management in the school, $40 \%$ of the respondents strongly agreed $50 \%$ also agreeing while $10 \%$ undecided. The findings therefore revealed that headteachers supervised time management in the school

\subsection{Challenges Faced by Headteachers in Managing Integrated Programmes}

The second objective was to identify the challenges faced by headteachers in management of public primary schools with integration programmes. The respondents were asked to indicate the challenges that they thought influenced the headteachers school management. In response, the data provided on Table 12 was elicited.

Table 12: Challenges Faced by Headteachers in Managing Integrated Programmes

\begin{tabular}{|c|l|c|c|c|c|c|}
\hline & Challenges Faced & SA & A & UN & D & SD \\
\hline 1 & Inadequate school management skills & 22.2 & 58.3 & 0 & 11.1 & 8.3 \\
\hline 2 & Inadequate school structures & 13.9 & 66.7 & 0 & 11.1 & 8.3 \\
\hline 3 & Few SNE trained teachers & 22.2 & 69.4 & 0 & 8.3 & 0 \\
\hline 4 & Lack of enough classrooms & 11.1 & 58.3 & 8.3 & 13.9 & 8.3 \\
\hline 5 & Too many pupils in a class & 13.9 & 50 & 5.5 & 19.4 & 8.3 \\
\hline 6 & Lack of enough teaching and learning resources & 26.9 & 61.5 & 3.8 & 3.8 & 3.8 \\
\hline 7 & Breakages and damages of resources by learners & 34.6 & 50 & 7.7 & 7.7 & 0 \\
\hline 8 & Truancy & 42.3 & 42.3 & 0 & 11.5 & 3.8 \\
\hline 9 & Lack of strategic plans & 10 & 50 & 0 & 20 & 20 \\
\hline 10 & Poor balancing of teachers & 0 & 40 & 0 & 30 & 30 \\
\hline 11 & High cost of living and materials & 60 & 40 & 0 & 0 & 0 \\
\hline 12 & Instability of prices for commodities in the market & 60 & 40 & 0 & 0 & 0 \\
\hline 13 & Too much workload for the headteachers & 50 & 40 & 10 & 0 & 0 \\
\hline 14 & External and political interference & 10 & 30 & 10 & 40 & 10 \\
\hline
\end{tabular}

The study established that $58.3 \%$ respondents said that headteachers did not have management skills in management of the resources for the integration programmes. Thus poor managerial skills due to lack of training compromised their effectiveness.

Findings reveal that majority (66.7\%) agreed that inadequate school structures were one of the challenges they faced in management of schools. These makes the running of the school difficult since handling many students with the 
limited resources is challenging The findings further reveal that Few SNE trained teachers affected the effectiveness of the school. Further, the study established that among the challenges is the Lack of enough classrooms leading to too many pupils in a class as it affected the classroom management and the overall school effectiveness.

The study results also show that $61 \%$ of the respondents indicated that Lack of enough teaching and learning resources and Breakages and damages of resources by learners was a major challenge to headteachers management. Truancy was also reported as a problem in management of the integration programme since a pupil who is absent misses a lot for being out of school.

Findings from the study show that majority respondents indicated that lack of strategic plans by the schools is one of the management challenges that headteachers face. As a consequence they find challenges in the implementation of school policies and plans. It is conceptualized that availability of strategic plans would form a base indicator for quality and standards of school resource management.

High cost of living and materials and Instability of prices for commodities in the market were also highlighted as some of the challenges in management of integration programmes. This is because the pupils have to be fed, and the learning materials have to be bought and with the prices of every commodity escalating rapidly, this poses a great challenge in the resource management.

The study results also show that $40 \%$ respondents indicated that external influence was a major challenge to school management. The external influences reported estimated form political and community interests.

\subsection{Strategies to Mitigate to Negative Factors influencing Management of Schools}

The third objective was to identify the strategies to address challenges to effective management of public primary schools by headteachers. Data from the respondents indicated that among the major strategies include training, and increased government funding to schools. Table 13 shows the strategies that the study established.

Table 13: Strategies to Mitigate the Negative Factors influencing Management of Schools

\begin{tabular}{|l|c|c|c|c|c|c|}
\hline \multicolumn{1}{|c|}{ Strategies } & SA & A & UN & D & SD & $\%$ \\
\hline Increased government funding and grants & 25 & 62.5 & 3.13 & 9.4 & 0 & 100 \\
\hline $\begin{array}{l}\text { Increased share of government infrastructure funds to enable schools } \\
\text { to put up adequate physical facilities to cater for the rising enrolment }\end{array}$ & 28 & 53 & 3.13 & 15.6 & 0 & 100 \\
\hline Minimum transfer of teachers & 40.6 & 53 & 3.13 & 3.13 & 0 & 100 \\
\hline Head teachers training on financial and management & 9.4 & 65.6 & 12.5 & 12.5 & 0 & 100 \\
\hline Employment of more teachers & 31 & 59 & 6.3 & 3.1 & 0 & 100 \\
\hline Increased involvement of SMCs in school management & 38 & 59 & 3 & 0 & 0 & 100 \\
\hline
\end{tabular}

Legend: S A (Strongly agree-scored 5), A (Agree-scored 4), UN (Undecided-scored 3), DA (Disagree-scored 2), and SDA (Strongly Disagree- scored 1)

Regarding the issue of lack of managerial financial and management skills by headteachers is to ensure that in order to qualify to be chosen as a headteachers one must have some minimum professional training on management as reflected or be given an in-service training on financial and management skills. The government should organize seminars and workshops to brief the headteachers on the management constrains and ways of dealing with them.

The findings further reveal that most respondents belief that employing more SNE trained teachers by the teachers service commission would alleviate the problem facing headteacher who have resulted in employed unqualified teachers to meet the current shortfall. The study further established that majority of the respondents have the opinion that increased involvement of SMCs in school management would alleviate the headteachers burden as they have enormous workloads

This they said would be mitigated by increased government funding and provision of grants. Currently funds for free primary education are low and the school management has to cope with the challenges of meeting the financial demands in running these institutions. The study further established that increased share of government infrastructure funds to primary school would enable schools to put up adequate physical facilities and material resources to cater for the rising enrolment as result of FPE.

It is clear from the above that participants in this study are aware of the solutions to the challenges facing headteachers in management of integration programmes. Being the chief executive of the school, the headteacher is the key to effective management of the school. A prime task of school head teacher is to exercise leadership of the kind that 
results in a shared vision of the directions to be pursued by the school, and to manage change in ways that ensure that the school is successful in realizing the vision.

\section{Conclusion}

Based on the findings discussed in the previous chapter, this study concludes that head teachers were found to be relatively effective in most of the aspects of integration programmes resource management which included: physical, material, human and financial resource management.

The major focus of this study was to investigate how the Head teachers manage the resources for the implementation of integration programmes for the intellectually challenged learners in primary schools in Maara district. It can be concluded that the headteachers were effective in management of the school resources for the integration programmes. However, they faced the following setbacks; inadequate physical resources such as resource rooms, workshops and dormitories, inadequate teaching and learning materials and books. Lack of management training by the headteachers, lack of strategic plan, irregular and inadequate government funding, instability of prices in the market, few SNE trained teachers, understaffing and truancy were also some of the challenges highlighted.

\section{References}

Bennett, N.\& Cass, A. (1989). From Special to Ordinary School. London: Cassell

Berg, B.L. (1995). Qualitative research methods for the social sciences. Second edition. London: Allyn and Bacon.

Borg, W. R \& Gall, M .D. (1984). Educational Research an Introduction, $5^{\text {th }}$ New York: Longman Inc.

Borg,W. R. \& Gall, M. D.(1986). Educational Research an Introduction (6 th $^{\text {Ed}}$.). White Plains, NY: Longman.

Bush \& Oduro, (2000). School Managers in the Context of Globalization. New York:

Campher, T., Caprio, G. and Honoham, P. (2002). Managing school finances. Sandown: Heinemann.

Chapman, J.D., Froumin, I.D. \& Aspin, D.N. (1999). Creating and managing the democratic school. London: The Falmer Press.

Creswell, J.W.( 2003). Research design: Qualitative, quantitative and mixed methods approaches. Second edition. London: Sage Publications.

Dimmock (1996). Problems Facing School Managers In England.: New York: Oxford University Press

Douglass H.R (1964) The High School Curriculum, 3rd Edition, New York: Ronald Press

Earley, P.C. (1999). The transplanted executive: Why you need to understand how workers in other countries see the world differently. New York: Oxford University Press.

Gay, L. R. (1981). Educational Research Competencies for Analysis and Application: New Yolk: Ohio Macmillan Publisher.

Goodlad, J.I. (1975). The dynamics of educational change. London: McGraw-Hill Book Company.

Halber \& Davies. (2002). Challenges Facing B.O.Gs in School Management. A Journal of Comparative Education Review. 39(6) 112126.

Harbey, C. \& Dadey, A. (1993). The Job of Headteacher in Africa: research and reality. International Journal of Educational Development, 13(2), 147-160.

Harris \& Lambert, (2003). Management Functioning of Schools. Lagos ; Mac Millan Publishers.

Harris, A., Day, C., Hopkins, D., Hadfield, M., Hargreaves, A. and Chapman, C. (2003). Effective leadership for school improvement. New York: Routledge.

Head, A. \& Watson, D. (1995). Corporate finance: Principles and practices. London: Pitman Publishing.

Hegarty, S. \& M. Alur (eds) (2002). Education and Children with Special Needs. New Delhi: Sage.

Hutt S.J (1988). Outside the mainstream, a history of special education. London: Batsord limited

Jackson, T. (2002). International HRM: A cross-cultural approach. California: Sage Publications, Inc.

Kauffmaan MJ \& Payne SJ 1975 introduction and personal perspectives. Columbus Olto: A Bell and Howell company.

Kerlinger, F.N. (1986). Foundations of Behavioral Research (3rd ed.). New Delhi: Holt, Rinehart and Winston.

Kombo, D. \& Tromp, D. (2006). Proposal and Thesis Writing: An Introduction. Nairobi: Pangoline Publications Africa.

Kruger, A.G. \& Van Schalkwyk, O.J. (1993). Classroom management. Pretoria: Academica.

Leithwood, K.A. \& Stainback, J.(1995). Preparing school leaders for educational improvement. London: Croom Helm.

MacDonald, N (2007). Educational Management. MacDonalds Institute of Archeological research.

Marcus, A.J. (1996). Essentials of investments. Boston: McGraw-Hill//rwin.

McMillan, J.H. \& Schumacher, S. (2006). Research in Education. Evidence-Based Inquiry. Sixth edition. New York: Longman.

Mugenda, O. \& Mugenda, A. (1999). Research methods. Quantitative \& qualitative approaches. Nairobi: Acts Press.

Mujis.D \& Harris .A. (2003). Teacher leadership: Improvement through empowerment.

Ngugi, W. (2002). Introduction to inclusive Education, 1st ed. Nairobi: KISE.

Njeri, W. J. (1996). Preparation of Secondary School Headteachers and Implications on their Administrative Performance. A Case Study of Nairobi Province. Unpublished Masters Thesis. Kenyatta University.

Orodho, J. (2004). Techniques of Writing Research Proposals and Report. Nairobi: KISE. 
Randiki,.O. (2002). Historical Development Of special needs education. Nairobi: KISE

Rarieya, J. F. A. (2007). School Leadership in Kenya: the lived realities of women heads of schools. Unpublished PhD. Dissertation. Keele University.

Rena B.L \& Doorlag D.H (1987) Teaching special students in the mainstream, 2nd Edition. Toronto: Merill Publishing Company.

Sagor, R. \& Barnett, B.G. (1994). The TQE principal. New York: Corwin Press Production.

Sallis, E. (1997). Total quality management in education. Second edition. London: Kogan Page Limited.

Sanders, W. (2001). Controlling for student background in value-added assessment of teachers. Journal of Educational and Behavioral Statistics, 29(1), 37-65.

Stewart, A.M. (1994). Empowering people. Great Britain: Bell and Bain Ltd.

Teachers' Service Commission (2000). Scheme of Service for Graduate Teachers. Retrieved on 25th January (2007) from http://www.tsc.go.ke/.

UNESCO, (2004). EFA Global Monitoring Report 2006: Literacy for Life. Paris: UNESCO.

Uwheraka, T. (2005) Analysis of space dimensions and physical facilities in senior public secondary schools, Unpublished Med dissertation, delta state university, Abraka.

Van Deventer, I. \& Kruger, A.G.( 2005). An educator's guide to school management skills. Pretoria:

Witaker, S. (2003). The Scope of Management Challenges in The Context of School Environment. New Delhi: Vikas 